Dominik Bień

https://doi.org.10.26881/ae.2020.17.09

ORCID: 0000-0001-7033-8216

Uniwersytet Gdański

Agnieszka Bień

ORCID: 0000-0001-5357-628X

\title{
Analiza pól problemowych związanych z rolą nauczyciela w wybranych rocznikach „Przeglądu Pedagogicznego”
}

\section{Wprowadzenie}

We współczesnej Polsce prestiż zawodu nauczyciela wydaje się spadać. Pojawiają się również różnego rodzaju trudności wywołane problemami społecznymi, rozwojem technologii informacyjnych czy choćby ostatnio pandemią koronawirusa. Wszystkie te zjawiska prowadzą do ewolucji czy rewolucji (jak w ostatnich miesiącach) w pracy nauczyciela. Ich skutkami są również poczucie zagubienia i trudności zawodowe niektórzy pedagodzy nie wiedzą, jak i czego powinni uczyć. Dzieje się tak także w związku ze zmieniającymi się wytycznymi prawnymi i narzucaną przez rządzących koniecznością dostosowania efektów nauczania do potrzeb rynku pracy. Wydaje się, że w tym chaosie trudno odnaleźć się przynajmniej części nauczycieli oraz tym, którzy bezpośrednio lub pośrednio stykają się z tematem nauczania i szkoły. Celem artykułu jest sięgnięcie do tradycji polskiej myśli pedagogicznej na podstawie jednego z najważniejszych i najstarszych periodyków pedagogicznych w Polsce "Przeglądu Pedagogicznego" - i odnalezienie w nim tradycyjnego rozumienia roli nauczyciela. Nie uważamy jednak, że takie ujęcie jest zawsze lepsze od współczesnego, nie szukamy „raju utraconego” w minionych modelach edukacji. Sądzimy natomiast, że stojąc przed wyzwaniami współczesności, nie możemy zapominać o przeszłości jako rezerwuarze koncepcji możliwych do wykorzystania dzisiaj.

Tytułowe czasopismo ukazywało się w latach 1882-1939 (aczkolwiek kilka lat przed odzyskaniem przez Polskę niepodległości zmieniano kilkukrotnie jego nazwę; 
do pierwotnej wróciło w 1917 roku [zob. Grabowska 2015: 68-72]). Ostatni numer „Przeglądu Pedagogicznego” ukazał się w 1939 roku. Później periodyk o takim samym tytule ukazywał się w latach 1970-1975 jako czasopismo Instytutu Badań Pedagogicznych (Nukat). Trudno jednak w tym przypadku mówić o ciągłości. W 2007 roku na Uniwersytecie Kazimierza Wielkiego w Bydgoszczy powstał kolejny „Przegląd Pedagogiczny”, którego jednak nie należy traktować jako kontynuacji istniejących wcześniej czasopism. Jego twórcy na stronie internetowej informują, że ich zamiarem nie jest „zawłaszczanie istniejącej tradycji. Pragniemy wydawać nowe pismo o zasięgu ogólnopolskim, które będzie odzwierciedlało stan dyscypliny naukowej, jaką jest pedagogika, a także stymulowało nowe kierunki badań, ważne z punktu widzenia praktyki społecznej” (O Przeglądzie Pedagogicznym).

W artykule zostanie przedstawione, w jaki sposób używano terminu „nauczyciel" i jak rozumiano rolę tej postaci w trzech rocznikach tytułowego czasopisma: u początków jego funkcjonowania (1887), w końcu lat trzydziestych (1939) i we współczesności (2016). W związku z tym przejrzano artykuły, w których po raz pierwszy ujęto określone rozumienie roli i pojęcia nauczyciela $w$ danym roczniku. Pomijano te teksty, które powielały wcześniejsze ujęcia. Chociaż między „Przeglądem Pedagogicznym” z XIX i XX wieku a współczesnym periodykiem nie ma łączności formalnej i organizacyjnej, analiza tego przekroju może przynajmniej cząstkowo przybliżyć zmiany zachodzące w rozumieniu pojęcia i roli nauczyciela na przestrzeni tych 130 lat.

Dobór roczników był podyktowany chęcią objęcia analizą jak najszerszego zakresu czasowego. Pierwszy dostępny online ${ }^{1}$ numer czasopisma pochodził z 1887 roku. Wydawał się odpowiedni dla zarysowania samoświadomości nauczycieli w początkach czasopiśmiennictwa pedagogicznego na terenach Polski. Rocznik z 1939 roku jest z kolei symptomatyczny ze względu na to, że jest ostatnim w II RP i ogniskują się w nim tendencje na pograniczu ideologii i wychowania schyłku dwudziestolecia międzywojennego. Ponadto w zawartych w nim tekstach daje się wyczuć atmosferę zagrożenia wojennego i reakcję na nią środowiska nauczycielskiego. Wybór rocznika 2016 ma na celu domknięcie analizy i doprowadzenie jej do XXI wieku.

\section{Rocznik 1887}

Wydaje się, że w 1887 roku rozumienie roli nauczyciela było konstruowane w odniesieniu do kilku podstawowych obszarów: wiedzy i umiejętności, podmiotu kształcącego i kształconego, trudności związanych z pracą w zawodzie oraz relacji z innymi uczestnikami procesu edukacji (uczniów, rodziców, nauczycieli). Poniżej znajduje się skrótowa rekonstrukcja każdego z tych obszarów.

\footnotetext{
${ }^{1}$ Dostęp elektroniczny był istotny ze względu na trudności w dostępie do archiwów i bibliotek związane z pandemią COVID-19.
} 


\section{Nauczyciel w kontekście umiejętności}

Uważano, że nauczyciel wykazuje (lub powinien wykazywać) określone umiejętności związane z kształceniem uczniów, a także dysponuje konkretnymi wiadomościami z prowadzonego przedmiotu. Takie rozumienie pojawia się w artykule $O$ rozpowszechnianiu znajomości literatury, gdzie pożądane cechy dydaktyka określa się w kontekście umiejętności przekazywania wiedzy: „dobry nauczyciel zatrzymuje uwagę uczniów po przeczytaniu utworu nad jego cechami charakterystycznemi" (Łagowski 1887: 1). Nauczyciel wskazywany jest również jako ten, który ze względu na rozeznanie w danej dziedzinie potrafi doradzić uczniom, na co mają zwracać uwagę podczas lektury: „młodzież studyjująca pod okiem nauczyciela znajdzie uzupełnienie wiadomości przez wykład lub inne środki, które wskaże nauczyciel, podczas gdy szersza publiczność i młodzież nie słuchająca wykładów, potrzebuje nie tylko ułatwień, ale i zachęty, podniety" (Łagowski 1887: 2).

Do umiejętności przekazywania wiedzy (tym razem z zakresu geografii) odnosi się również autor artykułu Odczytywanie map przy nauce geografii. Dodatkowo jednak zwraca on uwagę na pomaganie oraz „ustawiczne sprawdzanie” (Odczytywanie... 1987: 4-5), co oznacza, że nauczyciel powinien mieć poczucie służby rozumianej jako niesienie pomocy oraz systematyczność w sprawdzaniu wiedzy ucznia. Poza umiejętnościami podejmowany jest również temat pomocy technicznych (w przedmiotach tego wymagających). Ich dostępność i umiejętność ich wykorzystywania powinna mieć wpływ na sposób prowadzenia lekcji (Odczytywanie map przy nauce geografi, ciag dalszy 1887: 3-4).

Karol Rawer podejmuje zagadnienie nauczycielskich umiejętności w kontekście wyższych wartości („miłość” i „interes najwyższy”). Opisuje on dwie formy nauczania. Pierwsza to heurystyczna, „którą zwą także sokratyczną, dyjalogiczną, lub wreszcie katechetyczną” - polega „na obopólnej wymianie myśli między nauczycielem a uczniem". Rolą nauczyciela w tej formie jest kontrolowanie przyswojonego materiału oraz przychodzenie „z pomocą samodzielnemu rozwojowi ich myśli” (Rawer 1887: 2-3). W drugiej, akromatycznej (wykładającej), „nauczyciel sam opowiada o czemś w ciągłym wykładzie, pozostawiając zrozumienie tego, co mówi, pojętności i dobrej woli uczniów" (Rawer 1887: 2-3). Według autora prostszą formą nauczania jest wykładowa, ale i w jej wypadku należy mieć określone przymioty. Rawer radzi, powołując się na słowa Trentowskiego:

Wlej najwyższy interes w każdy przedmiot nauczania twego [...]. Celu tego dopniesz bez trudności, skoro sam wszelką naukę cenisz wysoko i potrafisz przedstawić ją z duchem. Nim udasz się na lekcyję, usiłuj natchnąć się przedmiotem! Natchnienie twe obudzi wnet w uczniach podobne natchnienie. Kochaj sam przedmiot, a uczniowie go kochać będą, bo miłość roznieca łatwo miłość, a gdzie miłość tam interes najwyższy - oraz Nagelsbacha - z prawdziwym zajęciem i ciepłem powinien nauczyciel uczyć [...] a ciepło to pokryje niejeden błąd nauczyciela, wynikający z braku doświadczenia; żaden zasób wiadomości nie zastąpi tego ciepła (Rawer 1887: 2-3). 
Ostatecznie według autora istotne wydają się dwie cechy: zainteresowanie nauczanym przedmiotem oraz zapał do nauczania jako procesu przekazywania wiedzy.

Rawer oprócz tego przekazuje nauczycielom wskazówki szczegółowe. Są to między innymi: dostosowanie sposobu przekazywania wiedzy i jej poziomu do wieku i umiejętności ucznia (za Trentowskim wskazuje wręcz: „zapomnij w czasie lekcyi twej jaźni [...] a przeistocz się w jaźń uczniów" [Rawer 1887: 2-3]); sumienne przygotowanie do prowadzonych zajęć; utrzymanie wysokiego poziomu językowego wykładu („Myśl musi jasno odbić się w umyśle ucznia” [Rawer 1887: 2-3]) i jednoczesne unikanie stylu zbyt „kwiecistego i retorycznego” (Rawer 1887: 2-3).

\section{Kształcenie nauczycieli}

Istotnym tematem poruszanym w poszczególnych artykułach jest kształcenie czy samokształcenie nauczycieli. W tekście Walny zjazd nauczycieli i przyjaciót szkolnictwa w Pradze Czeskiej autor podkreśla, że w przygotowaniu do zawodu nauczyciela trzeba, by

poświęcano więcej starania pedagogice w ogóle i dydaktyce; aby kandydaci do stanu nauczycielskiego nabywali większej znajomości praktycznej metod nauczania w pomnożonych klasach szkół wzorowych; aby przy egzaminach nauczycieli na umiejętność stosowania teorii w praktyce baczniejszą zwracano uwagę; i aby w tym celu na nauczycieli w seminariach brano doświadczonych b. kierowników szkół niższych (Król 1887a 6).

Do ustawicznego kształcenia zachęca też w odpowiedziach dla czytelników redakcja, odpisując pytającej: „nauczyciel dbać winien nie tylko o fachowe wykształcenie, ale ciągle i wszechstronnie ma się kształcić, to jednak przede wszystkim obowiązkiem jest jego poznać to, co go najbliżej dotyczy, to jest pedagogiją w najobszerniejszym znaczeniu tego słowa" (Odpowiedzi... 1887: 8). Redaktor przytacza całą listę książek, które mają dopomóc $\mathrm{w}$ dokształceniu się i poznaniu pedagogiki.

\section{Warunki pracy nauczyciela}

Odrębne zagadnienia szeroko poruszane w „Przeglądzie” są związane z trudnościami finansowymi i warunkami pracy. Do pierwszej strony zawodu nauczyciela odnosi się Teodor Tomasz Jeż w artykule Edukacyja kobiet w Szwajcarii, w którym opisuje próbę podwyższenia pensji szwajcarskim nauczycielom. W odczuciu społecznym podwyższenie poziomu materialnego nie jest potrzebne, by dydaktycy "obowiązki swe pełnili należycie” (Jeż 1887a: 3) - wystarczy kontrola ze strony władz i administracji. Mimo że poruszany przez Jeża problem dotyczy państwa odległego geograficznie i kulturowo od Polski, wydaje się, że ze względu na prezentacje ich polskiemu czytelnikowi stanowi on wyznacznik dla możliwych rozwiązań $\mathrm{w}$ rodzimym systemie edukacji.

W czasopiśmie pojawia się również problem przeciążenia pracą. W sprawozdaniu ze zjazdu czeskich nauczycieli przytoczono postulat, „,aby liczbę uczniów w klasie 
ograniczono przynajmniej do 60 i o ile można mniej obarczano nauczycieli zajęciami kancelaryjnemi" (Król 1887b: 6) - wydawało się to równie istotnym roszczeniem dla przynajmniej części polskich dydaktyków.

Autor tekstu Poszanowanie wieku dziecinnego podejmuje kwestie problemów jednostkowych przymiotów poszczególnych nauczycieli. Zauważa, że nawet dydaktycy, którzy są „dobrymi, pracowitymi ludźmi” (B.M. 1887: 1), nie zawsze utrzymują wysoki poziom swojej pracy. Podczas spotkań z uczniami często zapominają, że mają „przed sobą dziecko, delikatną roślinę, której każdy niezdrowy podmuch zaszkodzić może, istotę, której niewinność domaga się poszanowania” (B.M. 1887: 1). Część z nich, nawet jeśli pamięta „o tem przy wejściu do szkoły”, nie „zdoła utrzymać się w takim stanie ducha przez cały ciąg swego w niej zajęcia” (B.M. 1887: 1). Dochodzi wówczas do sytuacji, w których używają „wyrazów obelżywych” albo kierują się niecierpliwością i niedelikatnością, „które w dzieciach budzą złość, niechęć do nauki” (B.M. 1887: 1). Podobnie dzieje się, gdy pracę w szkole podejmuje nauczyciel łatwo zniechęcający się do uczniów „odznaczających się wadami” (B.M. 1887: 1). Nie zadaje on sobie wówczas trudu „zbadania przyczyn złego, próbowania sposobów wywabienia tych plam charakteru, ale potępia chore na duszy dziecko" i okazuje „mu pogardę; tym sposobem pogłębiając jeszcze to złe, dozwalając tym plamom do gruntu duszy przesiąknąć” (B.M. 1887: 1).

Powyższe trudności często usprawiedliwia się tym, że „zawód nauczycielski jest tak ciężki, iż niepodobna wymagać ciągłej pogody umysłu od pedagoga” (B.M. 1887: 1). Autor jednak je odrzuca, wskazując, „że są nauczyciele, którzy mimo ciężkiej pracy wyznają, że gdy wchodzą do klasy, pozostawiają u jej progu wszelkie troski, czują się jakby w świątyni, dziecinne twarzyczki wywierają na nich wpływ kojący bóle: tacy wytworzyć zdołają tę atmosferę duchową, o którą nam chodzi” (B.M. 1887: 1).

Praktykę działania pedagogów z idealnym wzorcem zestawia Wincenty Dawid (ojciec Jana Władysława Dawida):

Piękne to, idealne przymioty nauczyciela ta ojcowska wyrozumiałość, pełne pedagogicznej miłości zachęcanie dzieci słowami otuchy, ale niezupełnie praktyczne w szkołach publicznych, gdzie wyjątkowo chyba przychodzą stosownie przygotowani umysłowo, iż mogą się nie opóźniać w postępach i z sercem tyle uszlachetnionem, że tej rozsądnej i ojcowskiej dobroci nauczycieli nie wezmą za słabość charakteru (Dawid 1887: 2).

Ostatecznie jego zdanie o nauczycielach jako o grupie nie jest pozytywne. Uważa, że uczniowie powinni wychodzić z lekcji z tak dużym zasobem wiedzy,

aby korepetytorowi nie pozostawało nic więcej, jak przekonać się, czy uczeń zrozumiał przedmiot, i powtórzeniem ugruntować go w jego pamięci. Ale najczęściej jest to tylko pobożne życzenie, którego spełnienie w większej części zależy od nauczyciela, od jego doświadczenia, taktu i biegłości w wykładzie, od przymiotów bardzo rzadko, jak obecnie spotykanych” (Dawid 1887: 2).

Trudno powiedzieć, na ile ocena Dawida pokrywała się z rzeczywistością. Sprawdzenie tego wymagałoby szerokich badań historycznych na temat nauczycieli na ziemiach polskich pod koniec XIX wieku. 


\section{Nauczyciel jako uczestnik relacji}

W „Przeglądzie Pedagogicznym” nauczyciel jest opisywany również jako uczestnik różnych relacji. Jedną z podstawowych wydaje się ta między nim a uczniem. W zależności od autora jest ona traktowana albo w sposób czysto praktyczny lub utylitarny (jej głównym celem jest transmisja wiedzy i umiejętności) albo w sposób pogłębiony (jako wypełnienie misji, realizacja wyższych wartości itp.). Nauczyciel pozostaje także w relacjach z innymi aktorami życia szkolnego - innymi pedagogami oraz rodzicami.

Relację nauczyciela z rodzicem opisuje Henryk Wernic w artykule Baczność na wychowanie domowe. Uzupełnia w ten sposób relację nauczyciel-uczeń pojawiającą się we wcześniejszych artykułach o postać rodzica. Wysiłki stworzonego w ten sposób trójkąta, którego wierzchołki są ściśle od siebie zależne, są nakierowane na dobro i rozwój dziecka. Wernic wskazuje na trudności z utrzymaniem dyscypliny wśród uczniów: „Dawniej pod groźbą kary cielesnej, łatwiejsze było utrzymanie subordynacyi w szkole, niż dzisiaj, kiedy prądy czasu, regulamina szkolne i większa znajomość psychologii nie pozwala ich używać" (Wernic 1887a: 1). Dlatego, zdaniem Wernica, szkoła ma większe prawo wymagać od rodziców odpowiedniego wychowania dzieci, „iżby takich wychowańców dostarczali szkole, którzy nie sprawią jej zbytecznego kłopotu i przykrości, a dobrem słowem w zupełności kierować się dadzą" (Wernic 1887a: 1). Niestety często „rodzice zbytecznie przez palce patrzą na pewne wady, jak: lenistwo, brak wytrwałości, lekkomyślność, nieschludność, niegrzeczność, niezgodność itd., z któremi nauczyciele długą i częstokroć bezowocną staczać muszą walkę" (Wernic 1887a: 1). Autor wskazuje, że aby lepiej kontrolować wpływ wywierany na ucznia zarówno przez rodziców, jak i nauczycieli, ci pierwsi powinni „przynajmniej raz lub dwa razy w miesiącu zapytywać władzy szkolnej lub odnośnych nauczycieli o postęp i sprawowanie swych dzieci. Wychowańcy wiedząc, że żadne przekroczenie szkolne nie ujdzie wiadomości ich rodziców, powstrzymywać się będą w swej niesforności” (Wernic 1887a: 1).

Relacja nie pozostaje bez wpływu na nauczyciela, ponieważ „takie jednozgodne działanie domu ze szkołą jeszcze z drugiej strony pociąga za sobą bardzo błogie następstwa, bo dodaje bodźca nauczycielom do usilniejszej pracy na swem stanowisku; każdemu bowiem miło jest spostrzedz, że umiemy ocenić jego działalność" (Wernic 1887a: 1). Jednocześnie relację między nauczycielem a uczniem odróżnia autor od ojcowskiej, a porównuje do braterskiej: „Niechaj nauczyciel postępuje z uczniami, jak starszy ich brat. Braterskie postępowanie wyraźniej charakteryzuje stosunek, jaki powinien zachodzić pomiędzy nauczycielem i uczniem niż pseudo-ojcowskie" (Wernic 1887a: 2).

Wernic podkreśla również konieczność współpracy między samymi nauczycielami i stosowania takich samych norm wobec uczniów, podając jako przykład sytuację, w której 
jeden nauczyciel małym przewinieniom, pochodzącym z tak zwyczajnej lekkomyślności w młodym wieku, nadawać będzie wielkie znaczenie, a drugi i na większe boczenia przez palce patrzeć będzie; jeśli z uczniem znajdującym się już na drodze poprawy postępować będzie tak, jak postępował wówczas, kiedy wszelkie przedstawienia żadnego na nim nie wywierają wrażenia, to wpływ umoralniający szkoły będzie bardzo niewielki (Wernic 1887a: 2).

W kolejnym artykule ten sam autor dzieli nauczycieli pod kątem stosowanych przez nich kar, wiążąc ten temat ze światopoglądem wychowawców:

Zaiste, karność bywa bardzo rozmaita. Jedni nauczyciele, a ci niestety znajdują się u nas w większości, nie umieją jej utrzymać bez całego zasobu środków przymusowych; drudzy, a tych jest bardzo niewielu, używają tylko najlżejszych kar i to bardzo rzadko, a są i tacy, którzy nigdy się do nich odwoływać nie potrzebują. Pierwsi są konserwatystami w pedagogice i chcą tak postępować, jak z nimi za ich młodości postępowano; drudzy odwołują się do dobrych elementów istniejących w duszy każdego wychowańca (Wernic 1887b: 1).

Autor zdecydowanie staje po stronie nauczycieli postępowych. Uważa, że „karność" można utrzymać wśród uczniów, nie sięgając do szerokiego zasobu kar (za przykład podaje szkołę francuską). Karność szkolną przeciwstawia wojskowej, wskazując, że ta druga „dąży do przytłumienia w żołnierzu stojącym w szeregu wszelkiej indywidualności, władzy myślenia a nawet woli”, tymczasem w „szkole [...] idzie o najswobodniejszy rozwój wychowańca" (Wernic 1887b: 1). Nauczyciel ma być w tym procesie „akuszerem ułatwiającym rodzenie się przymiotów, zalet i cnót wychowańca, ale nie jest ich ojcem ani twórcą" (Wernic 1887b: 2). Podsumowując, autor stwierdza, że „chcąc skutecznie kierować młodzieżą, trzeba przede wszystkiem czynić to $\mathrm{z}$ największym spokojem umysłu: $\mathrm{z}$ jednej strony więc nie przewidywać z góry nieprzyjemności, jakie nas w szkole spotkać mogą, z drugiej dobrze wiedzieć, co w danym razie uczynić należy" (Wernic 1887b:2). Dodatkowo niezbędne jest „zjednanie sobie serc wychowańców, to jest działanie na ich uczucia” (Wernic 1887c: 2).

Kolejnym wątkiem poruszanym przez Wernica jest powinność sprawiedliwego traktowania ucznia oraz zachowanie ostrożności w relacjach z nim. Warto przytoczyć tutaj szerszą wskazówkę praktyczną, jaką autor daje nauczycielom:

Nieraz się zdarza, że uczeń uprzedza się do nauczyciela, nie lubi go, stawia mu opozycyją, chociaż dla innych zupełnie jest uległy. Uprzedzenia tego mogą być najrozmaitsze przyczyny: niesłuszne podejrzenie rzucone na niego przez nauczyciela, pomimowolna obelga lub coś podobnego. Uczeń widocznie czyni wszystko, aby dokuczyć nauczycielowi: nie uważa na lekcyi, płata psoty i figle, a nawet dopuszcza do niesubordynacyi. Podobne zdarzenie wymaga nadzwyczajnej ostrożności i przezorności, bo łatwo uprzedzenie ucznia udzielić się może większej gromadce jego kolegów, a wówczas nauczyciel nie będzie mógł sobie dać rady ze zbuntowaną przeciwko sobie gromadką. Uchronimy się od tego działając wprost na uprzedzonego młodzieńca. Przywołajmy go po lekcyi do osobnego pokoju i tam, we cztery oczy, przedstawmy niesłuszność jego postępowania. Zapytajmy jaką ma do nas urazę i do czego dąży swoją niesfornością? Powiedzmy mu, że tak postępując, nie tylko sobie samemu czyni krzywdę, ale daje zły przykład całej klasie, na co w żaden sposób pozwolić nie możemy. Przypomnijmy, że według obowiązujących szkolnych przepisów, moglibyśmy go skazać na tę lub inną karę, ale nie czynimy tego, bo sądzimy, że słowa nasze go 
opamiętają i przekonają, że jesteśmy jego prawdziwym przyjacielem, a nie wrogiem, że więc i on nie powinien po nieprzyjacielsku z nami postępować. Zażądajmy wreszcie, żeby nam podał rękę i dał słowo, że zmieni swe postępowanie (Wernic 1887b: 2).

Wydaje się, że takie wskazówki praktyczne (zarówno w kwestiach metodycznych, jak i nauczania określonych przedmiotów) były dla ogółu nauczycieli bardzo cenne ze względu na brak dostępu do innych form dokształcania. W powyższym cytacie zwraca również uwagę koncyliacyjne, a wręcz partnerskie podejście, które według Wernica powinno cechować nauczyciela. Ostatecznie jednak bezdyskusyjne pozostaje, że to dydaktyk ma rację i że to jego argumenty mają zostać przyjęte.

Antoni Rink w artykule Dr Karol Volkmar Stoy rysuje relacje nauczyciela i uczniów (również między sobą) w odniesieniu do założeń herbartyzmu. Autor, omawiając funkcjonowanie „zakładów Stoya”, stwierdzał, że rolą dydaktyka jest „wychowanka [...] doprowadzić w jak najkrótszym czasie do samodzielności w kierunku intelektualnym i moralnym przez stopniowe rozwijanie w [...] myśleniu i czynach" (Rink 1887: 6). Uszczegółowieniem tak przyjętej roli było zminimalizowanie w określonym zakresie bezpośredniego wpływu pedagoga:

uczniowie sami mogli wyprowadzić, wywnioskować, tego nauczyciel nie mówił. Wynik i materyjał naukowy musieli samodzielnie wygłaszać, a nauczyciele z psychologicznych względów jak najmniej mogli im pomagać w produkcyjach i reprodukcyjach wykładów szkolnych. Uczniowie musieli sobie nawzajem przeglądać ćwiczenia i błędy oznaczać, poczem każdy był zmuszony własnoręcznie je poprawić (Rink 1887: 6).

Według kolejnego autora, Stanisława Berżańskiego, główną pożądaną cechą nauczyciela jest cierpliwość: „rozważając sumiennie działanie moje wychowawcze, przekonałem się, że największe błędy pedagogiczne, jakich się dopuściłem, pochodziły z braku cierpliwości, chociaż powszechnie twierdzono, iż byłem bardzo cierpliwy" (Berżański 1887: 1). Wskazuje on, że „cierpliwość jest nie tylko puklerzem, od którego odbijają się wszelkie przykrości, nieodłączne od powołania nauczycielskiego, ale jednym z głównych warunków powodzenia w tym zawodzie" (Berżański 1887: 1). Dodaje także, że cecha ta przydaje się w szczególności, nauczycielom ludowym, których „wysokiem zadaniem jest kształcić i wychowywać nieokrzesane a częstokroć i nieschludne biedne dziatki naszego ludu" (Berżański 1887: 1).

Źródeł niecierpliwości Berżański upatruje na przykład w słabym zdrowiu, rozdrażnieniu nerwowym, a także w podejściu naturalistycznym - wiary w to, że „sztuka wychowawcza najbardziej jest podobna do sztuki ogrodniczej. Ponieważ zaś ogrodnik pielęgnuje, podlewa rośliny, a nieraz je gwałtownie nagina, obcina nożem lub wyrywa, przeto nauczyciele cholerycznego temperamentu biorą stąd pochop do używania gwałtowniejszych środków, uważając je za jedyne skutecznie" (Berżański 1887: 1). Dzisiaj tego typu poglądy mogą wydawać się niepoważne, ale w XIX wieku organicystyczne analogie wydawały się uzasadnione wśród przedstawicieli nauk społecznych (najjaskrawszym przykładem tego są rozważania Herberta Spencera). 


\section{Rocznik 1939}

Od 1919 roku „Przegląd Pedagogiczny” wydawało Towarzystwo Nauczycieli Szkół Średnich i Wyższych (TNSŚiW) jako jedno z czasopism organizacji (drugim było „Muzeum”). Periodyk w tym okresie „informował o sprawach organizacyjno-związkowych i zajmował się problematyką szkół średnich, na jego łamach przedstawiano sposoby nauczania w innych krajach, omawiano nowe metody, starano się znaleźć sposób na polepszenie pozycji zawodowej nauczyciela w Polsce”, a „Muzeum” "zajmowało się problematyką naukowo-pedagogiczną, szczególnie dydaktyką w szkołach średnich" (Durka 2014: 47).

Na styku nauczania z polityką i ideologią

Charakter ideologiczny czasopisma (szczególnie pod koniec lat trzydziestych XX wieku) można określić jako silnie prawicowy. W artykule T.N.S. W a O.Z.N czytamy, że organizacja wydająca „Przegląd Pedagogiczny” jest apolityczna, ale „deklaracja p. pułkownika Koca, stanowiąca podstawy Obozu Zjednoczenia Narodowego, zawiera te same zasady wychowania narodowego i religijnego, o które organizacja nasza [...] walczyła z górą pół wieku" (T.N.S.W a O.Z.N 1939: 1). Dla członków TNSŚiW szczególnie istotne są: zbieżność interesów narodu i państwa, „ścisły związek Narodu naszego z Kościołem katolickim", odrzucenie komunizmu i walki klas, armia jako czynnik, „dookoła którego w każdym niebezpieczeństwie Naród zjednoczyć się potrafi”, cel nauki rozumiany jako „dostarczanie dla Narodu i Państwa nowych elementów bogactwa i siły" (T.N.S.W a O.Z.N 1939: 1). O prawicowym charakterze organizacji świadczy również zakaz przyjmowania do niej nauczycieli żydowskich (Sprawy ideowo-programowe 1939: 9). Na tych przykładach widać, jaką drogę przebył „Przegląd Pedagogiczny" od czasów, kiedy redaktorem naczelnym był Jan Władysław Dawid, a pismo miało charakter bardziej liberalny czy lewicowy.

Do analizy kontekstu politycznego posłuży rocznik czasopisma z 1939 roku. Jeden z jego pierwszych artykułów jest poświęcony Romanowi Dmowskiemu. Autorzy określają polityka mianem „nauczyciela młodego pokolenia” (Roman Dmowski [1864-1939] 1939: 3), wskazując wpływ, jaki wywarł na młodzież poprzez Myśli nowoczesnego Polaka i Przewrót. Zawód nauczyciela porzucił, aby przed I wojną światową stać się mężem stanu. Ostatecznie jednak jego rola pedagoga nie została zapomniana, o czym świadczą ,tłumy młodzieży z różnych ugrupowań politycznych, które szły za trumną tego bojownika o sprawę narodową”, które „wiodła moc idei, sięgających ponad stronnictwa i orientacje, moc wdzięczności dla nauczyciela i wychowawcy" (Roman Dmowski [1864-1939] 1939: 3). W takim ujęciu zadaniem nauczyciela jest nie tylko oddziaływanie na ucznia w kontekście szkolnym, ale również w sensie symbolicznym na całą (lub część) polskiej młodzieży.

Henryk Galle (1939: 1-5) odwołuje się do wychowania patriotycznego, analizując przemówienia Wojciecha Świętosławskiego. Patriotyzm rozumie jednak 
przede wszystkim jako pracę „konstruktywną i twórczą, wynikającą bezpośrednio z głęboko przemyślanej polskiej racji stanu" (Galle 1939: 3). W pracy tej istotną rolę ma nauczyciel jako wychowawca, a także dom i rodzina, ostatecznie zaś cały naród. Autor zatem przedstawia dydaktyka jako część większej całości stanowiącej wartość samą w sobie - narodu, na którego rzecz należy rozwijać oświatę i kulturę. W ujęciu Gallego jednak, mimo że nauczyciel jest podporządkowany wartościom narodowym, zachowuje w dużym stopniu swoją autonomię.

O preferowanych horyzontach myślowych nauczyciela pisze Marian Piątkiewicz. Uznaje on, że poza skupieniem na własnym przedmiocie pedagog nie powinien tracić „,sprzed oczu celów nadrzędnych, do których zmierza cała szkoła, żeby zawsze w swojej specjalnej pracy pamiętał o tych podstawach ideowych, na których się szkoła opiera" (Piątkiewicz 1939: 3). Do wspomnianych podstaw zalicza - poza wychowaniem obywatelskim i państwowym - również wychowanie religijne. Ograniczenie działalności nauczyciela tylko i wyłącznie do osiągania celów państwowo-obywatelski „zamyka życie człowieka tylko granicami ziemskimi do doczesności, nie otwiera perspektyw szerszych, dalszych, nie mówi o człowieku jako o istocie nieśmiertelnej, która ma przed sobą cele ponadziemskie, wieczne" (Piątkiewicz 1939: 4). Co więcej, odnosząc się do celów religijnych, jednoznacznie opartych na katolicyzmie, autor wskazuje, „by wśród wszystkich nauczycieli mogła zapanować jednomyślność poglądów na tę sprawę. Ta jednomyślność i jednozgodność w tej jak zresztą w innych sprawach świetnie podtrzymuje autorytet szkoły, a przecież całe dzieło wychowania, a więc istotny cel szkoły, jest nie do pomyślenia bez utrzymania autorytetu" (Piątkiewicz 1939: 4). Piątkiewicz prezentuje wizję nauczyciela całkowicie zamkniętego na odmienność światopoglądową i etyczną, wiernego wyłącznie religii katolickiej.

Wychowanie z ideologią i polityką wiąże autor artykułu Nauczycielstwo obok armii. Tytułowe zestawienie wynika $\mathrm{z}$ narastającego poczucia zagrożenia wojną z III Rzeszą. Autor uważa, że nauczyciele są nie mniej ważni w przygotowaniu narodu do zbliżającego się konfliktu niż armia. Rola pedagogów powinna polegać na ideowym „przygotowaniu młodzieży do obrony kraju, ku wyrobieniu i zahartowaniu w niej woli wielkości i zwycięstwa”, a także na gotowości „nauczycielstwa zrzeszonego w naszej organizacji do poświęcenia wszystkiego czego odeń w razie potrzeby wymagać Ojczyzna i honor Narodu" (Nauczycielstwo obok armii 1939: 1). Poczucie zagrożenia, a także wezwanie do mobilizacji przebijające przez tekst artykułu wskazują na faktyczne włączenie się nauczycieli w przygotowania do nadchodzącego konfliktu.

W kolejnych numerach czasopisma problem przygotowania do zbliżającego się konfliktu zbrojnego tylko się nasila. W tekście W obliczu zjazdu (1939: 3-5) poruszony jest problem samoorganizacji nauczycieli w kierunku wychowania militarnego przed ewentualnym jego umożliwieniem przez przepisy prawa. Takie wychowanie, według autora, będzie sprawiało duże trudności związane dodatkowo 
z koniecznością utrzymania dotychczasowego poziomu kształcenia. Trudność pogłębia wielokrotnie poruszany dotychczas problem - niedostateczne wynagrodzenie, a przez to niski poziom życia, zwłaszcza młodych nauczycieli.

\section{Postulaty zawodowe}

Istotne miejsce w omawianym roczniku zajmują artykuły poruszające tematy typowo materialne i postulaty o charakterze zawodowym. Wydaje się to świadczyć o tym, że mimo silnego powiązania z patriotyzmem i religią linia czasopisma była przynajmniej w pewnym stopniu krytyczna wobec ówczesnych władz. Taki charakter ma Memoriał Zarządu Głównego TNSW do Pana Wicepremiera, Ministra Skarbu. Jego sygnatariusze wskazują, że nauczyciele szkół średnich ogólnokształcących są znacznie gorzej wynagradzani od pozostałych dydaktyków: „nawet nauczyciel szkoły powszechnej, mający wyższe studia, jest zobowiązany wprawdzie do większej liczby godzin tygodniowo, ale finansowo jest właściwie lepiej sytuowany, mianowicie bierze to samo uposażenie, co nauczyciel szkoły średniej, a nadto otrzymuje dodatek mieszkaniowy" (Memoriał Zarządu Głównego TNSW... 1939: 4). Niskie pensje powodują „,brak kandydatów do zawodu nauczycielskiego, dający się obecnie odczuwać we wszystkich działach szkolnictwa i grożący poważnym obniżeniem jakości szkół w Polsce" (Memoriał Zarzadu Głównego TNSW... 1939: 4-5). Niedostatek, który dotyka nauczyciela, jest tu wyraźnie zarysowany. Jego sytuacja staje się przedmiotem programu zmian, do których należą: wprowadzenie stypendiów dla studiujących nauczycieli, zwiększenie uposażenia młodego dydaktyka co najmniej do poziomu podporucznika w Wojsku Polskim, zwrot za kształcenie dzieci nauczycieli, brak możliwości awansu dla doświadczonych nauczycieli, wsparcie nauczycieli w szkołach prywatnych (Memoriał Zarządu Głównego TNSW... 1939: 5-6). Program zmian przewija się wielokrotnie przez numery czasopisma jako stawiany podczas wszelkiego rodzaju narad, posiedzeń i spotkań $\mathrm{z}$ władzami. W wielu numerach jest to temat dominujący i sytuuje organizację jako związek zawodowy, a czasopismo jako jego organ. W tym kontekście wielokrotnie pojawiają się artykulacje problemów również nauczycieli szkół prywatnych, wyraźnie oddzielanych od tych pracujących w państwowych placówkach, a których sytuacja materialna jest znacznie gorsza.

Do trudności praktycznych w zawodzie nauczyciela odnosi się Zofia Alchimowicz, według której „mamy dotychczas tak słabo rozwiniętą sieć szkolnictwa powszechnego, że w szkołach wyżej zorganizowanych w ośrodkach miejskich klasy są przepełnione nadmiernie, a nauczycielstwo przeciążone pracą" (Alchimowicz 1939: 11), co odbija się na wynikach egzaminów do szkół średnich.

$\mathrm{O}$ realnym położeniu nauczyciela w społeczeństwie informuje autor artykułu Groźna przyszłość. Wymagałoby szerszych badań stwierdzenie, na ile prezentowany opis oddawał stan faktyczny, a na ile jest to publicystyczna hiperbola. W każdym razie jego treść przedstawia nauczycielską codzienność w czarnych barwach: 
wśród obecnie czynnych nauczycieli rodzi się depresja, zamiast zapału, zgorzknienie - zamiast entuzjazmu życia; [...] wśród młodego pokolenia nauczycielstwa szkół średnich niewiele spotykamy jednostek dzielnych, zapalonych do pracy, rozmiłowanych w zawodzie - [...] naprawdę groźnym jest to, że zawód nauczycielski stracił wszelką atrakcyjność, że stanowisko nauczyciela upadło w hierarchii społecznej do poziomu lekceważonego i zaledwie tolerowanego pariasa, że obecna młodzież akademicka „karierę nauczycielską" uważa za zwichnięcie kariery w ogóle, za katastrofę życiową, za nieszczęście! (Groźna przyszłość 1939: 9).

Autor bije na alarm, uznając, że bez poprawy sytuacji materialnej nie ma szansy na budowanie kadr nauczycielskich na wartościowych jednostkach.

Podsumowując, w omawianym roczniku nacisk został przeniesiony z relacji nauczyciela z uczniami, rodzicami i innymi nauczycielami na relację z szeroko pojmowaną władzą państwową, która jest adresatem kolejnych postulatów i propozycji zmian. To państwo i jego przedstawiciele stają się kluczowymi aktorami w kreowaniu rzeczywistości szkolnej. Wybrzmiewa to w artykule Po pierwszym roku pracy liceum humanistycznego (Szwemin 1939: 6-9). Jego autor uznaje, że rola nauczyciela sprowadza się w dużym stopniu do stosowania nowych programów kształcenia, które musiał przyswoić w szybkim tempie (ze względu na ich późne rozpowszechnienie przez ministerstwo). Trudność sprawiało również niedostosowanie kształcenia nauczycieli na uniwersytetach do nowego programu, co powodowało konieczność przekazywania skryptów z nowymi zagadnieniami. W tym przypadku pedagog nie rysuje się jako podmiot nauczający na podstawie własnych umiejętności, wiedzy, doświadczeń, ale jako przedmiot wpisany w określoną strukturę, do której zmian musi się każdorazowo dostosowywać. Wolność wydaje się całkowicie zastąpiona posłuszeństwem wobec władz i tworzonych przez nie programów.

\section{Rocznik 2016}

„Przegląd Pedagogiczny” wydawany przez Uniwersytet Kazimierza Wielkiego różni się od swoich poprzedników. W przeciwieństwie do periodyku ukazującego się przed 1939 rokiem ma on charakter nie informacyjny i metodyczny, ale naukowy. Związana jest z tym często szersza i bardziej rozbudowana narracja w odróżnieniu od często skrótowych opisów w poprzednich rocznikach.

Analizie poddano dwa numery z 2016 roku. Wybór wskazanego rocznika wiąże się z tym, że był to ostatni rok przed szerszymi zapowiedziami wprowadzenia reformy szkolnictwa, a także przed rewolucją w punktacji czasopism, która doprowadziła do przetasowania na w listach periodyków. Stąd wydaje się, że w 2016 roku motywem do publikacji w określonych tytułach (w tym w „Przeglądzie”) mogło być kierowanie się jego znaczeniem w środowisku, nie zaś punktacją, która nie zawsze odpowiada temu znaczeniu.

W roczniku powracają tematy $\mathrm{z}$ lat poprzednich, ich oblicze i natężenie jednak są odmienne. Brakuje właściwie odezw do władz, charakterystycznych dla rocznika 
1939, co ma związek ze zmianą charakteru czasopisma. Podobnych postulatów należałoby aktualnie szukać w czasopismach i biuletynach prowadzonych przez związki zawodowe. Nadal pojawiają się artykuły krytyczne wobec rozwiązań systemowych w obszarze edukacji, ale ich ostrze jest skierowane przeciwko neoliberalnej formie kapitalizmu. Wyraźnie zarysowane są również tematy relacji nauczyciela z uczniami i rodzicami, a także nauczyciela wobec wartości.

\section{Wartości w pracy nauczyciela}

Karina Stępkowska w swoim artykule odnosi się do wartości, jaką jest sprawiedliwość. Autorka wskazuje, że „zadaniem [...] nauczycieli jest przygotowanie dzieci do życia w świecie za pośrednictwem sprawiedliwych wyborów" (Stępkowska 2016: 17). Oznacza to, że dydaktyk powinien nie tylko potrafić edukować dzieci w zakresie aksjologii, ale także samemu mieć poczucie sprawiedliwości, które może przekazać uczniom. Kształcenie w tym zakresie bez osobistego systemu wartości oraz wiedzy związanej z tym tematem wydaje się technicznie możliwe (przy użyciu np. pomocy technicznych), ale trudne do realizacji i etycznie wątpliwe.

Autorka wskazuje również na inne cechy, które powinien posiadać sprawiedliwy nauczyciel -„,musi być dobrym obserwatorem i potrafić odnaleźć w grupie tych samotnych, nieśmiałych czy odrzuconych z różnych powodów przez rówieśników i zaoferować im pomoc" (Stępkowska 2016: 23). Poza tym

każde działanie pedagoga powinno być dokładnie przemyślane, a [jego] oddziaływanie na tyle skuteczne, by dziecko czuło, że jest wyjątkowe i zawsze może liczyć na jego wsparcie. Nauczyciel i uczeń powinni być „zawodnikami grającymi w jednej drużynie”, dla których wynik jest jednakowo ważny. Narzędziem w ręku nauczyciela nie może być jedynie krytyka, groźba i kontrola ucznia (Stępkowska 2016: 23).

Dodatkowo sprawiedliwego nauczyciela musi charakteryzować „wyrozumiałość, życzliwość, umiejętność okazywania szacunku, bezinteresowność, konsekwencja” (Stępkowska 2016: 23). Zarysowany portret przypomina Weberowski typ idealny. W rzeczywistości jednak prawdopodobnie niewielu nauczycieli mogłoby sprostać powyższym wymaganiom.

W artykule dodatkowo zawarto przykłady niesprawiedliwego zachowania nauczycieli, a także wskazówki mające na celu zminimalizowanie takiego postępowania. Mają one formę praktycznych wskazówek i uszczegółowienia wcześniej sformułowanych cech o wysokim stopniu abstrakcji. Formę wskazówek mają również scenariusze lekcji przeznaczonych do realizacji.

$\mathrm{W}$ podsumowaniu autorka zauważa, że chociaż stawiane przez nią zadanie jest trudne do realizacji, to "gdy nauczyciel znajdzie własną do ucznia drogę" (Stępkowska 2016: 28), osiągnięcie celu stanie się możliwe. Uważa również, „że warto wychowywać dzieci w duchu sprawiedliwości i ku sprawiedliwości, by ją odczuwały i do niej indywidualnie w przyszłości zmierzały. Od tego zależą postępy demokracji 
i rozwój humanizmu" (Stępkowska 2016: 28). Nauczyciel w koncepcji autorki jest więc wpisany całkowicie w świat wartości, ale również w politykę, z którą powinien być związany poprzez popieranie demokratycznego systemu sprawowania władzy.

Podporządkowanie się nauczyciela wyższym celom postuluje także Maria Deptuła w opracowanym przez siebie raporcie. Przedstawia w nim (jako jeden z wątków) sygnalizowane przez uczniów problemy dotyczące postaw nauczycieli. Były to między innymi brak wsparcia ze strony dydaktyków w przypadku trudnych warunków pracy na lekcji (hałas, zdenerwowanie, zmęczenie) oraz brak zapewnienia ochrony przed uczniami z zaburzeniami zachowania. Jako potencjalne sposoby przeciwdziałania tym problemom autorka wskazuje konieczność działań systemowych, między innymi planowanie pracy z klasą, współpraca między nauczycielami i stosowanie programów profilaktycznych (Deptuła 2016: 127-149).

Autorka w podsumowaniu uznaje, że „dopóki nauczyciele będą określali swoją rolę w szkole jako «przerabianie programu», znaczna część uczniów nie będzie miała w niej warunków niezbędnych do rozwoju psychospołecznego" (Deptuła 2016: 148). Takie wytyczne wyraźnie wskazują, że w pracy nauczyciela niezbędne są: poczucie misji, przekraczanie podstawowych obowiązków i działanie mające na względzie nie realizację wytycznych, a dobro dziecka. Taka wizja wydaje się słuszna, ale może nie wytrzymać konfrontacji z materialną stroną zawodu nauczyciela i koniecznością pracy w trudnych warunkach, dużych klasach czy na kilku etatach.

Nauczanie w systemie neoliberalnym

Andrzej Olubiński, sytuując swoje rozważania na pograniczu polityki i pedagogiki, rozważa zagadnienie ludzkiej aktywności w systemie neoliberalnym oraz „pozornej demokracji”, w których „człowiek staje się istotą powierzchownie aktywną, przygotowaną głównie do biernej konsumpcji, «taśmowej» produkcji oraz reagującą na zewnętrzne bodźce” (Olubiński 2016: 33). Taki system wydaje się „kształtować osobowości autorytarne, bierne, nietwórcze: a w istocie wręcz psychofizycznie chore, bo niemające szans na pełną samorealizację oraz samourzeczywistnienie" (Olubiński 2016: 33).

Rola nauczyciela $\mathrm{w}$ tak zarysowanym systemie jest również powierzchowna może on uczyć pewnych technicznych umiejętności czy określonego rodzaju wiedzy, ale nie może być wychowawcą. Zamiast wychowawcy to

korporacyjny rynek oraz kontrolowane przez organa władzy określone obszary życia społecznego, powinny kształtować: indywidualnego oraz agresywnego egoistę, człowieka sukcesu, ale również człowieka uległego, służalczego, dyspozycyjnego, niesamodzielnego, nieautonomicznego, demagoga, ślepo wykonującego polecenia władzy, zdolnego do przyjęcia dowolnych zasad oraz wartości etycznych (Olubiński 2016: 38).

W takim systemie relacja mistrz-uczeń zostaje zdominowana lub zniesiona przez nastawienie (zarówno nauczyciela, jak i ucznia) na „odniesienie sukcesu za wszelką 
cenę [...] poprzez np. rozwijanie instrumentalnego rozumu, korzyści własnych czy «interesu narodu», bez zbędnych sentymentów oraz skrupułów (np. także poprzez postawy nieuczciwości, oszustwa, agresji lub zastraszania)" (Olubiński 2016: 38).

Nauczyciel w neoliberalnym kapitalizmie powinien również stosować się do określonych prawideł w kwestii egzekwowania swoich decyzji, to znaczy powinien być „autokratyczny w stosunku do uczniów oraz posłuszny i adaptacyjny w stosunku do poleceń władzy (politycznej oraz korporacji)” (Olubiński 2016: 39). Powinien być również wzorem „poprawnej politycznie aktywności konsumpcyjno-społecznej” poświęcającym swój czas na zadania biurokratyczne. Ostatecznie powinien być „wypalony oraz zagubiony i bezradny w rozwiązywaniu spraw wychowawczych” (Olubiński 2016: 39). Nauczyciel akademicki z kolei „powinien być aktywny w walce o pieniądze” (Olubiński 2016: 39) i popierać polityków.

Autor wskazuje opierający się na teorii krytycznej program zmian w szkole i roli nauczyciela, który ma przeciwdziałać rozwojowi systemu opartego na zasadach neoliberalnych. Olubiński stwierdza, że „pedagogowie krytyczni nie mają nic do stracenia: muszą demaskować ukryte cele edukacyjne służące reprodukowaniu wartości oraz przywilejów elit, produkujące bezrefleksyjne ludzkie przedmioty. Muszą poświęcić się na rzecz emancypacyjnych imperatywów upełnomocnienia i zmiany społecznej" (Olubiński 2016: 44). Nauczyciel w tym systemie wydaje się bardzo silnie wpisany w projekt polityczny. Właściwie polityka jest podstawą jego działalności pedagogicznej. Zerwano tutaj z pozytywistyczną neutralnością nauczania, z założenia oderwanego od polityki i ideologii. Wychowawca powinien zgodnie z projektami wywodzącymi się z myśli lewicowej sytuować się po stronie upośledzonych i poszkodowanych.

Do podobnych wniosków dochodzi Piotr Łaszczyca, który w swoich rozważaniach wychodzi od projektu neurodydaktyki. Zwraca uwagę, że cieszy się on wśród nauczycieli dużym zainteresowaniem, które jest „wynikiem oczekiwania, że rezultaty tych badań umożliwią rozwiązanie problemów, z którymi boryka się współczesna szkoła” (Łaszczyca 2016: 119). Autor szeroko rozwija temat biologicznych podstaw formowania umysłu człowieka, wiążąc następujący w tym kierunku rozwój badań w naukach społecznych z kapitalizmem jako systemem ekonomicznym oraz przemianami szkolnictwa w Polsce i na świecie. Prowadzone przez niego rozważania nie mają jednak związku z tematem naszego artykułu do momentu, w którym autor podejmuje temat kształtowania postaw uczniów z pokolenia Z, które to kształtowanie ma się stać również udziałem nauczycieli. Autor ostatecznie dochodzi do wniosku, że

w kontekście kształtowania postaw niepokoi [...] tendencja do unifikacji i formalizacji sposobów pracy nauczycieli oraz zacierania różnic ich osobowości. Służą temu standardowe narzędzia dydaktyczne wraz z lawinowo rosnącą sprawozdawczością i pseudoplanowaniem. Po części może to wynikać z obniżania się poziomu merytorycznego dydaktyków. Pracę podejmują bowiem wychowankowie silnie demotywującego systemu (Łaszczyca 2016: 116). 
Takie ukształtowanie sposobów pracy nauczycieli może mieć negatywny wpływ na uczniów, ponieważ „barwność charakterów i odmienność poszczególnych wychowawców składa się na różnorodność wewnętrzną szkoły i pozwala na indywidualne wybory wzorców przez ucznia" (Łaszczyca 2016: 136).

Według autora kryzys ten należy również powiązać z dyskusją nad relacją mistrz-uczeń i koniecznością przeciwdziałania temu, aby miejsca mistrza nie zajęli „patologiczni, przypadkowi przywódcy” (Łaszczyca 2016: 136). Autor przeciwstawia sobie również dwie wizje: nieznajdującą pokrycia w rzeczywistości, wręcz bajkową „nauczyciela wyposażonego w gabinet do pracy i pracownię, gotowego na eksperymenty, mającego czas na myślenie, dokształcanie i korektę pracy prezentują czasami filmy o szkole (np. «Stowarzyszenie umarłych poetów» z 1989 r. w reżyserii Petera Weira)" (Łaszczyca 2016: 136) oraz taką, w której ponadprzeciętnie rozwinięte uniwersytety rywalizują ze szkołami, tworząc na przykład uniwersytety dziecięce („deklaratywnie chwalebny cel ukrywa w gruncie rzeczy nędzę wynikającą z malejącego naboru studentów i gargantuicznego przerostu systemu szkolnictwa wyższego" [Łaszczyca 2016: 136]), zamiast kształcić nauczycieli. Do źródeł problemów dydaktyków autor zalicza dodatkowo kolejne reformy systemu edukacji, które pogłębiają niepewność wychowawców, a oprócz tego są każdorazowo źle skonstruowane.

Podsumowanie artykułu dotyczące sytuacji nauczycieli w szerszym kontekście systemowym jest zdecydowanie pesymistyczne: „W istniejącym obecnie w Polsce systemie oświaty mamy do czynienia z bezbronną szkołą, samotnym nauczycielem i roszczeniowym społeczeństwem. Nikt w tej sytuacji nie odpowiada za wychowanie młodzieży" (Łaszczyca 2016: 141).

Do problemów wynikających z szeroko rozumianej polityki i kształtowania ustroju szkoły odnosi się Barbara Adamczyk w recenzji książki Dzieło Janusza Korczaka wobec wyzwań XXI wieku. Specyfika relacji dziecko-dorosły. Do tytułowej relacji autorka zalicza relację uczeń-nauczyciel jako jedną z kilku istotnych w pedagogice. Mankamentem książki jest jej zdaniem brak propozycji „wykorzystania pedagogiki J. Korczaka w relacjach uczeń-nauczyciel na terenie szkoły" (Adamczyk 2016: 176). Miałoby ono polegać na wprowadzeniu demokracji i dialogu między dzieckiem a nauczycielami:

\footnotetext{
Wspomniana demokracja w szkole polegałaby m.in. na właściwym sposobie rozwiązywania problemów, dialogu i wzajemnym poznawaniu się członków społeczności szkolnej, właściwym partnerstwie wszystkich członków społeczności szkolnej, w tym także uczniów, współpracy społeczności szkolnej w działaniach dla poprawy swojego samopoczucia i warunków nauki i pracy, autentycznym udziale we współdecydowaniu o własnych sprawach przez samoorganizację i współrządzenie, poważnym traktowaniu dzieci, ich aktywizacji, rozwijaniu samorządności polegającej na współrządzeniu i współgospodarzeniu (Adamczyk 2016: 176).
}

W tej koncepcji, jak się wydaje, rola nauczyciela zostałaby w dużej mierze uszczuplona w ten sposób, że część istotnych decyzji podejmowali by sami uczniowie. 
Zdecydowanie polityczny wydźwięk ma tekst Bogusława Śliwerskiego, który przytacza zapisy Listu Otwartego do Nauczycieli i Wychowawców Towarzystwa Kursów Naukowych. Zgodnie z listem nauczyciele tworzący swój samorząd są jedną z istotnych grup (obok Rady Oświatowej, samorządów terytorialnych, rodzicielskich i uczniowskich), które stanowią o praktyce działania szkoły, i powinni być traktowani przez państwo jako realni partnerzy. W rzeczywistości tak nie jest. Wszystkie te grupy, łącznie z nauczycielami, funkcjonują jako upośledzony element w relacji z politykami. Jak wskazuje Śliwerski,

w ciągu minionego ćwierćwiecza niemalże każda rządząca partia polityczna potwierdziła swój wizerunek jako władzy odwracającej się od obywateli, antysolidarnościowej, tolerującej patologię we własnych strukturach i generującej ją w życiu publicznym, bezkrytycznej wobec własnych błędów i wypaczeń, nasilającej brutalizację kampanii wyborczych i niespełniającej składane społeczeństwu obietnice (Śliwerski 2016: 314).

Taki sposób sprawowania władzy przekłada się wprost na relacje szkolne. Powoduje to, że „żyjemy w nieustannej wojnie polsko-polskiej: MEN-sko-nauczycielskiej, kuratoryjno-samorządowej, samorządowo-kuratoryjno-dyrektorskiej, nauczycielsko-uczniowsko-rodzicielskiej itp." (Śliwerski 2016: 314). Śliwerski rysuje obraz nauczycieli jako podmiotu politycznego, dążącego do samoorganizacji oraz wpływu na rzeczywistość edukacyjną, wikłając się w ten sposób w konflikty z innymi podmiotami (na czele z zawodowymi politykami). Politycy z kolei zmieniają reguły awansu i funkcjonowania szkoły co prowadzi do antagonizmów nauczycieli między sobą oraz z innymi interesariuszami w systemie szkolnym.

Nauczyciel w relacjach - nowe wątki, stare problemy

Kilku autorów podejmuje tematykę relacji nauczyciela z uczniami i rodzicami. Motyw trudności współpracy tych trzech stron, znany już z poprzednich roczników, przybiera nową formę.

W tekście Wirtualna koncepcja człowieka sukcesu - codzienność - rzeczywistość szkolna Magdalena Kolber analizuje związek między medialnym wizerunkiem człowieka sukcesu („młodym, atrakcyjnym, spełnionym osobiście i zawodowo” [Kolber 2016: 78]) a jego jakością życia. W ostatniej części artykułu autorka pisze o roli szkoły w przygotowaniu uczniów do rzeczywistości. Według Kolber współczesna szkoła nie uczy akceptacji niepowodzeń. Właściwie nie rozmawia się tam o tym, co nieudane. Dotyczy to także nauczycieli, którzy powinni według niej (oraz cytowanego przez nią Bogusława Śliwerskiego) spotykać się i rozmawiać na temat porażek własnych oraz innych osób. Autorka uznaje, że

źródłem niektórych problemów szkolnych, takich jak wypalenie, bezsilność, bezradność, depresja, jest nieumiejętność zaakceptowania porażki oraz przeżywanie jej w samotności. Omówienie ich z innymi osobami pozwala spojrzeć na porażkę z dystansu i skonfrontować własną opinię ze zdaniem osób trzecich, niezaangażowanych we własne trudności (Kolber 2016: 83). 
Najlepszym wyjściem według autorki jest zachowanie równowagi w kształceniu uczniów i rozwiązywaniu problemów nauczycieli na podstawie odnoszonych sukcesów i ponoszonych porażek.

W artykule (Nie)Zaufanie społeczne względem samodzielności edukacyjnej rodziców w homeschoolingu (Mazurek 2016: 88-102) zawarty jest temat przedefiniowania roli rodziców, a przez to również dzieci i nauczycieli, za sprawą nauczania domowego. Dydaktycy tracą w nim swoją dominującą pozycję, a przejmują ją rodzice, którzy w tradycyjnych formach byli tylko elementem wspierającym w procesie kształcenia. Nauczyciel pozostaje tylko i wyłącznie egzaminatorem albo konsultantem w edukacji dzieci, a rodzic staje się nauczycielem. W jakimś sensie prowadzi to do przełomu, ponieważ żeby nauczać, nie trzeba mieć przygotowania pedagogicznego czy nawet ukończonych studiów. Należy jednak pamiętać, że jest to zmiana na niewielką skalę i dotyczy głównie relacji rodzic-dziecko, a nie całej rzeczywistości szkolnej.

Joanna Nowak, w omówieniu badań dotyczących wizji pracy nauczyciela w przyszłości, w których wzięli udział studenci wczesnej edukacji, za podstawowe zadanie dydaktyka uznaje „wspieranie rozwoju dzieci, łączenie wszystkich obszarów i tworzenie holistycznej perspektywy rozwojowej”, co rozumie jako „niesienie pomocy dziecku w samodzielnym zdobywaniu wiedzy, doświadczenia, umiejętności, które przyczynią się do zmiany rozwojowej na każdym etapie rozwoju" (Nowak 2016: 118). Opierając się na koncepcjach pedagogiki humanistycznej, autorka wskazuje też na konkretne sposoby wsparcia dziecka i zadania w nich nauczyciela (laudacyjno-motywacyjne, sterujące, semisterujące, sterująco-oferujące, oferujące). Wspólne w wymienionych sposobach wsparcia jest wymaganie od nauczyciela "postawy podmiotowego, empatycznego traktowania dziecka, uwzględnienia jego potrzeb i poszanowania godności” (Nowak 2016: 120). Według niej wypowiedzi badanych „wydają się mieć niewiele wspólnego z przyjętym rozumieniem wsparcia, partnerstwa. W wyobrażeniach tych dominuje obraz wszechwładnej roli nauczyciela-wychowawcy, a nie wyobrażenie o procesie obustronnych, poprawnych relacji” (Nowak 2016: 122).

Badając relacje między nauczycielem a rodzicami, autorka zauważa, że ankietowani pozostawiają na jej boku podstawowy podmiot, którym jest uczeń, koncentrują się natomiast na indywidualnej odpowiedzialności nauczyciela za współpracę z rodzicami. Jednocześnie „w wyobrażeniach [...] studentów nauczyciel-wychowawca ma władzę, wymaga zarówno od dzieci, jak i rodziców, dyscypliny, posłuszeństwa, działania zgodnego z określonymi wskazówkami" (Nowak 2016: 124). Sposoby pracy nauczyciela mają, w zależności od respondenta, charakter zarówno odtwórczy, jak i twórczy. W pierwszym przypadku dotyczą realizacji podstawy programowej. W drugim „przyszły wychowawca ma świadomość poszukiwań sposobów pracy z dziećmi, wsparcia ich ze strony rodziców. Sytuacje edukacyjne łączy z obszarami rozwojowymi dziecka i pragmatyką działań” (Nowak 2016: 124). 
Wnioski płynące z artykułu nie są optymistyczne. Wydaje się, że przyszli nauczyciele mają trudności z otwartym, humanistycznym podejściem do uczniów i rodziców. Relacje z nimi w większym stopniu opierają się na nakazach i realizowaniu wymogów zawartych w regulaminach, wytycznych czy różnego rodzaju aktach prawnych niż na kreatywnym kształtowaniu „osobistych, interpretatywnych i komunikacyjnych kompetencji” (Nowak 2016: 125).

\section{Wnioski}

Podczas analizy kategoryzacji roli przypisywanej nauczycielowi w poszczególnych rocznikach „Przeglądu Pedagogicznego” można odnaleźć zbieżności, pojawiające się mimo ponad 100 i 80 lat odległości czasowej. Wyraźnie rysują się również różnice. Należy także wskazać na to, że właściwie w każdym z roczników nauczyciele występują w dwóch postaciach - tzn. realnie istniejących pedagogów ze swoimi problemami oraz przywarami i zaletami, a także pedagogów idealnych, czyli takich, jakimi powinni się stać według autorów artykułów. Podobnie wygląda kwestia sytuacji materialnej - rzeczywistość zestawia się z programami zmian.

Do podobieństw między poszczególnymi rocznikami czasopism zaliczyć można:

- ujmowanie nauczyciela w relacji z rodzicami i uczniem. Jednakże siła relacji pomiędzy poszczególnymi podmiotami jest różnie zarysowana - od marginalizowania rodziców aż po prawie całkowite odsunięcie na bok nauczyciela w nauczaniu domowym;

- zaznaczenie trudnej sytuacji materialnej i zawodowej nauczyciela (niewielkie wynagrodzenia, duże klasy, brak możliwości awansu itp.) przy jednoczesnym zarysowaniu programów zmian (wydaje się, że najbardziej precyzyjne postulaty występują w roczniku 1939);

- spoglądanie na nauczyciela w kontekście jego umiejętności nauczania oraz wiedzy z zakresu dziedziny, którą się zajmuje;

- powiązanie z działalnością nauczyciela różnego rodzaju pomocy szkolnych, począwszy od podręczników w pierwszych rocznikach aż po narzędzia e-learningowe w ostatnich;

- sytuowanie nauczyciela w kontekście pełnionej przez siebie misji; ujmowany jest na przykład jako starszy brat czy osoba o koniecznym nastawieniu etycznym;

- traktowanie nauczyciela jako podmiotu wąsko rozumianych działań politycznych - jako tych, którzy formułują postulaty do władz różnych szczebli o poprawę swojego bytu, ale też jako część większych tworów politycznych: organizacji zawodowych, samorządu, narodu.

Przy każdym z roczników można wskazać również różnice w rysowaniu roli nauczyciela. Przykładowo pierwsze roczniki „Przeglądu Pedagogicznego” osadzone są bardziej w nurcie postępowym i w większym stopniu kładą nacisk na autonomię nauczyciela oraz nowoczesne metody nauczania (relacjonując np. sposoby uczenia 
w Szwajcarii, Francji czy Czechach). W 1939 roku silnie wybrzmiewają tendencje nacjonalistyczne i konieczność powiązania nauczania $\mathrm{z}$ wiarą chrześcijańską. Pojawiają się również próby powiązania działalności nauczyciela z wychowaniem patriotycznym i militarnym. W najnowszych numerach czasopisma ponownie silna wydaje się tendencja polityczna, ale bardziej o zabarwieniu lewicowym. Przejawem takiego osadzenia nauczyciela są odwołania do teorii krytycznej, przeciwstawienie tendencjom neoliberalnym oraz sprzeciw wobec działań władz po 1989 roku.

\section{Literatura}

Literatura podmiotu

Adamczyk B., 2016, Dzieło Janusza Korczaka wobec wyzwań XXI wieku. Specyfika relacji dziecko dorosty, „Przegląd Pedagogiczny” nr 1.

Alchimowicz Z., 1939, Rola społeczna prywatnej szkoły powszechnej, „Przegląd Pedagogiczny" nr 1.

B.M., 1887, Poszanowanie wieku dziecinnego, „Przegląd Pedagogiczny” nr 10.

Berżański S., 1887, Cierpliwości, „Przegląd Pedagogiczny” nr 14.

Dawid W., 1887, Z życia szkoły, „Przegląd Pedagogiczny” nr 4.

Galle H., 1939, O lepsze jutro (Cele i środki pracy oświatowej w świetle przemówień P. Ministra W.R. i O.P. prof. dr Wojciecha Świętosławskiego, „Przegląd Pedagogiczny” nr 4.

Groźna przyszłość, 1939, „Przegląd Pedagogiczny” nr 4.

Jeż T.T., 1887a, Edukacyja kobiet w Szwajcarii, „Przegląd Pedagogiczny” nr 1.

Jeż T.T., 1887b, Edukacyja kobiet w Szwajcarii, ciag dalszy, „Przegląd Pedagogiczny” nr 2.

Kolber M., 2016, Wirtualna koncepcja człowieka sukcesu - codzienność - rzeczywistość szkolna, „Przegląd Pedagogiczny” nr 2.

Król K., 1887a, Walny zjazd nauczycieli i przyjaciót szkolnictwa w Pradze Czeskiej, „Przegląd Pedagogiczny" nr 1.

Król K., 1887b, Walny zjazd nauczycieli i przyjaciót szkolnictwa w Pradze Czeskiej, ciag dalszy, „Przegląd Pedagogiczny” nr 3.

Łagowski F., 1886, O rozpowszechnianiu znajomości literatury, „Przegląd Pedagogiczny” nr 1.

Łaszczyca P., 2016, Kuna w kurniku i biologia nauczania, czyli o tym jak neurodydaktyka włącza się do sporu o szkołę, „Przegląd Pedagogiczny” nr 1.

Mazurek E., 2016, (Nie)Zaufanie społeczne względem samodzielności edukacyjnej rodziców w homeschoolingu, „Przegląd Pedagogiczny” nr 2.

Memoriał Zarzadu Głównego TNSW do Pana Wicepremiera, Ministra Skarbu, 1939, „Przegląd Pedagogiczny" nr 1.

Nauczycielstwo obok armii, 1939, „Przegląd Pedagogiczny” nr 6.

Nowak J., 2016, „Zanim rozpocznie się szkoła...” - wyobrażenia studentów wczesnej edukacji o pracy nauczyciela - wychowawcy uczniów pierwszej klasy, „Przegląd Pedagogiczny” nr 2.

Odczytywanie map przy nauce geografii, 1887, „Przegląd Pedagogiczny” nr 1.

Odczytywanie map przy nauce geografi, ciag dalszy, 1887, „Przegląd Pedagogiczny” nr 2.

Olubiński A., 2016, Podmiotowa aktywność wtasna jako szansa samorealizacji i rozwoju

(wświetle założeń edukacji humanistycznej i krytycznej), „Przegląd Pedagogiczny” nr 2.

Piątkiewicz M., 1939, Podstawy ideowe naszej szkoly, „Przegląd Pedagogiczny” nr 11. 
Rawer K., 1887, O formach nauczania, „Przegląd Pedagogiczny” nr 5.

Rink A, 1887, Dr Karol Volkmar Stoy, „Przegląd Pedagogiczny” nr 13.

Roman Dmowski (1864-1939), 1939, „Przegląd Pedagogiczny” nr 1.

Sprawy ideowo-programowe, 1939, „Przegląd Pedagogiczny” nr 7-8.

Stępkowska K., 2016, Znaczenie kategorii sprawiedliwości w procesie wychowania dzieci w młodszym wieku szkolnym, „Przegląd Pedagogiczny” nr 1.

Szwemin J., 1939, Po pierwszym roku pracy liceum humanistycznego, „Przegląd Pedagogiczny" nr 3.

Śliwerski B., 2016, Kryzys oświatowej demokracji w świetle makropolitycznych badań pedagogicznych, „Przegląd Pedagogiczny” nr 2.

T.N.S.W a O.Z.N, 1987, „Przegląd Pedagogiczny” nr 5.

W obliczu zjazdu, 1939, „Przegląd Pedagogiczny” nr 9-10.

Wernic H., 1887a, Baczność na wychowanie domowe, „Przegląd Pedagogiczny” nr 6.

Wernic H., 1887b, Kilka słów o karności w wychowaniu, „Przegląd Pedagogiczny” nr 7.

Wernic H., 1887c, Kilka słów o karności w wychowaniu, dokończenie, „Przegląd Pedagogiczny" nr 8.

Literatura przedmiotu

Durka J., 2014, Wybrane problemy z działalności wydawniczej Towarzystwa Nauczycieli Szkół Średnich i Wyższych w dwudziestoleciu międzywojennym [w:] Działalność instytucji wydawniczych na rzecz oświaty i edukacji w XX i pierwszych latach XXI wieku, red. I. Michalska, G. Michalski, Łódź: Wydawnictwo Uniwersytetu Łódzkiego.

Grabowska D., 2015, „Przegląd Pedagogiczny” okresu II Rzeczypospolitej wobec projektów reform kształcenia nauczycieli, „Acta Universitatis Nicolai Copernici. Pedagogika XXXI" z. 426.

O Przeglądzie Pedagogicznym, b.d., Przegląd Pedagogiczny, https://przegladpedagogiczny. ukw.edu.pl/cms/o-czasopismie/ [dostęp: 12.07.2021].

\section{Streszczenie}

W artykule dokonano analizy pól problemowych związanych z rolą nauczyciela w trzech rocznikach „Przeglądu Pedagogicznego” - z lat 1887, 1939, 2016. Wskazano, jak autorzy poszczególnych artykułów rozumieli tytułowe pojęcie i z czym wiązali rolę nauczyciela. W podsumowaniu wskazano na podobieństwa i różnice pojawiające się na przestrzeni lat $\mathrm{w}$ analizowanym obszarze. Podjęto również temat zmian charakteru samego czasopisma od metodycznego, poprzez zawodowe aż po naukowe.

\section{Słowa kluczowe}

nauczyciel, „Przegląd Pedagogiczny”, historia wychowania, czasopismo 


\section{Summary}

Analysis of problem fields related to the role of the teacher in selected years of the "Pedagogical Review”

The article analyzes the related to the concept of a role of a teacher in three years of "Pedagogical Review" in 1887, 1939, and 2016. It shows how the authors of individual articles understood the title concept and what they associated the role of a teacher with. The summary shows the similarities and differences that have appeared over the years in the analyzed area. The subject of changing the nature of the journal itself, from methodical, through professional, to scientific, was also discussed.

Keywords

teacher, „Pedagogical Review”, history of education, journal 